\title{
Prediction of higher heating value of oat grain and straw biomass
}

\author{
Krzysztof Górnicki ${ }^{1, *}$, Agnieszka Kaleta $^{1}$, and Radosław Winiczenko ${ }^{1}$ \\ ${ }^{1}$ Department of Fundamental Engineering, Faculty of Production Engineering, Warsaw University of \\ Life Sciences, Nowoursynowska 164, 02-787 Warszawa, Poland
}

\begin{abstract}
The aim of the study was modelling of HHV of oat (grain and straw) biomass. The content of ash, carbon, hydrogen, nitrogen, moisture, volatile materials and the higher heating value of oat (grain and straw) biomass was measured. The possibility of using twenty models from the literature to describe $\mathrm{HHV}$ of oat was examined. The following models: $\mathrm{HHV}=19.914-0.2324 \mathrm{~A}$ and $\mathrm{HHV}=-3.0368+0.2218 \mathrm{VM}+0.2601 \mathrm{FC}$ are recommended for determining of HHV of oat (RMSE of the range 0.130.28). The models based on ultimate analysis gave worse results in determination of HHV for oat.
\end{abstract}

\section{Introduction}

The heating value (HV) of a fuel is a measure of this fuel energy content. Heat of combustion and the calorific value are the other names of HV. The lower heating value (LHV) is a measure of the enthalpy change during combustion at constant pressure with water in a vapour state, whereas the higher heating value (HHV) measures discussed enthalpy change, but with water in a liquid state [1]. Generally speaking, the higher heating value informs about the amount of heat released during the complete burning of a fuel unit mass including the condensation enthalpy of liquid water as a combustion product under standard conditions [2]. HHV of a fuel belongs to the most important properties of solid fuels being necessary for the design and operation of the fuel combustion systems and enabling comparison of different fuels [3].

The HHV of fuels can be determined experimentally by burning a specimen in a adiabatic oxygen bomb calorimeter under controlled conditions. The calorimeter measures the changes between reactants and products enthalpy $[2,4]$. The higher heating value can be also approximately predicted using empirical models. As far as biomass fuels are concerned discussed correlations are based on ultimate and/or proximate analysis, physical or chemical composition, or structural analyses. Most of the developed models are linear $[5,6]$, however same of the correlations between HHV and the constituents of the analysis could be nonlinear $[7,8]$.

\footnotetext{
*Corresponding author: krzysztof_gornicki@sggw.pl
} 
Empirical models based on ultimate analysis correlate the HHV with the elemental composition of solid fuels (contents of $\mathrm{C}, \mathrm{H}, \mathrm{O}, \mathrm{N}, \mathrm{S}, \mathrm{Cl}, \mathrm{P}$ ). Among mentioned models are these taking into account only influence of carbon $[9,10]$ or carbon and hydrogen $[11,12]$. These are however models considering impact of several elements on HHV, e.g.: carbon, hydrogen, and oxygen [10,13], carbon, hydrogen, oxygen, and nitrogen [4,14] or carbon, hydrogen, oxygen, nitrogen, chloride, and phosphor [15].

Correlations based on proximate analysis give the relationship between the higher heating value and the results of the proximate analysis. Such an analysis determines the content of moisture, volatile matter, sulfur, fixed carbon, and ash. Among discussed correlations can be find ones considering impact of, among others, content of fixed carbon [7], ash [10], fixed carbon and volatile matter [13,16], fixed carbon, volatile matter, and ash [17].

Demirbas [18] developed empirical models for calculation of higher heating values of such liquid fuels as alcohols, alkanes, and vegetable oils. These models take into account the influence of fuel density and viscosity on HHV. Empirical formula based on chemical composition correlates the HHV with the saponification value and iodine value of vegetable oils [19] whereas formulas considering structural composition of lignocellulosic fuels pay respect to lignin content and extractive content [7,20].

The higher heating value of biomass fuels can be predicted by applying artificial neural network ANN [2,3,5,21,22].

Plants cultivated for energy purposes should have the following characteristic features: low solid requirements, high resistant to diseases and pests, high annual growth and high energy content namely higher heating value [23]. Therefore oat can be treated as a very good energy source because its calorific value is higher than the other cereals and it does not need high quality soil for growing. Moreover oat is very important as a phytosanitary plant in the cereal crops rotation. It should be underlined also that the oat grains show the lowest importance as far as consumption and fodder is concern [24,25].

The objectives of this study were to investigate the carbon, hydrogen, nitrogen, ash, moisture, and volatile materials content and the higher heating value and modelling of HHV of oat (grain and straw) biomass.

\section{Material and methods}

The studied material consisted of grains and straw of the Bingo variety oat.

The contents of moisture (MC), ash (A), and materials volatile (VM) were measured in the LECO TGA 701, whereas the contents of carbon, hydrogen and nitrogen in the LECO $628 \mathrm{CHN}$ analyser. The higher heating value was measured in a calorimetric bomb placed in calorimeter LECO AC 600. Fixed carbon content (FC) was calculated using formula [26]:

$$
100=\mathrm{A}+\mathrm{FC}+\mathrm{MC}+\mathrm{VM}
$$

Twenty of mathematical models were used to prediction of HHV (Table 1).

Values of the considered models constants (Table 1) are presented in Table 2.

The goodness of fit of the models to the experimental data was evaluated with the root mean square error RMSE: 


$$
\mathrm{RMSE}=\sqrt{\frac{1}{n} \sum_{i=1}^{n}\left(y_{\text {pre }}-y_{\exp }\right)^{2}}
$$

where $n$ denotes number of data, $y_{\exp }$ means experimental value, and $y_{\text {pre }}$ denotes predicted value.

Table 1. Mathematical models for prediction of biomass HHV.

\begin{tabular}{|c|l|c|}
\hline Model No. & Model $^{*}$ & References \\
\hline 1 & $\mathrm{HHV}=x_{0}+x_{1} \mathrm{~A}$ & {$[10]$} \\
\hline 2 & $\mathrm{HHV}=x_{0}+x_{1} \mathrm{FC}$ & {$[7,14]$} \\
\hline 3 & $\mathrm{HHV}=x_{0}+x_{1} \mathrm{FC}+x_{2} \mathrm{~A}$ & {$[27]$} \\
\hline 4 & $\mathrm{HHV}=x_{0}+x_{1} \mathrm{~A}+x_{2} / \mathrm{FC}$ & {$[27]$} \\
\hline 5 & $\mathrm{HHV}=x_{1} \mathrm{FC}+x_{2} \mathrm{VM}$ & {$[11,14,16]$} \\
\hline 6 & $\mathrm{HHV}=x_{0}+x_{1} \mathrm{FC}+x_{2} / \mathrm{VM}$ & {$[27]$} \\
\hline 7 & $\mathrm{HHV}=x_{0}+x_{1} \mathrm{~A}+x_{2} / \mathrm{VM}$ & {$[27]$} \\
\hline 8 & $\mathrm{HHV}=x_{0}+x_{1} \mathrm{VM}+x_{2} \mathrm{FC}$ & {$[10,27]$} \\
\hline 9 & $\mathrm{HHV}=x_{0}+x_{1} \mathrm{VM}+x_{2} \mathrm{~A}$ & {$[16,27]$} \\
\hline 10 & $\mathrm{HHV}=x_{0}+x_{1}(\mathrm{VM}+\mathrm{FC})$ & {$[13]$} \\
\hline 11 & $\mathrm{HHV}=x_{0}+x_{1} \mathrm{MC}+x_{2} \mathrm{FC}+x_{3} \mathrm{~A}$ & {$[6]$} \\
\hline 12 & $\mathrm{HHV}=x_{0}+x_{1} \mathrm{VM}+x_{2} \mathrm{FC}+x_{3} \mathrm{~A}$ & {$[27]$} \\
\hline 13 & $\mathrm{HHV}=x_{0}+x_{1} \mathrm{FC}+x_{2} \mathrm{~A}+x_{3} / \mathrm{VM}$ & {$[27]$} \\
\hline 14 & $\mathrm{HHV}=x_{1} \mathrm{FC}+x_{2} \mathrm{VM}+x_{3} \mathrm{~A}$ & {$[17]$} \\
\hline 15 & $\mathrm{HHV}=x_{0}+x_{1} \mathrm{C}$ & {$[1,9,10]$} \\
\hline 16 & $\mathrm{HHV}=x_{0}+x_{1}(\mathrm{C}+\mathrm{H})$ & {$[1]$} \\
\hline 17 & $\mathrm{HHV}=x_{1} \mathrm{C}+x_{2} \mathrm{H}$ & {$[11]$} \\
\hline 18 & $\mathrm{HHV}=x_{1} \mathrm{~N}+x_{2} \mathrm{C}$ & {$[4]$} \\
\hline 19 & $\mathrm{HHV}=x_{0}+x_{1} \mathrm{~N}+x_{2} \mathrm{C}$ & {$[4]$} \\
\hline 20 & $\mathrm{HHV}=x_{0}+x_{1} \mathrm{~N}+x_{2} \mathrm{C}+x_{3} \mathrm{H}$ & {$[4]$} \\
\hline
\end{tabular}

*A - ash content, wt $\%, \mathrm{C}$ - carbon content, wt $\%, \mathrm{FC}$ - fixed carbon content, $\mathrm{H}-$ hydrogen content, $\mathrm{wt} \%, \mathrm{~N}-$ nitrogen content, $\mathrm{wt} \%, \mathrm{VM}-$ volatile materials content, $\mathrm{wt} \%$, $x_{0}-x_{3}-$ models constant

Significance of the impact of biomass kind (grain and straw of oat) on ash, carbon, hydrogen, nitrogen, moisture and volatile materials content and on the HHV was determined using ANOVA (after accepting the uniformity test of Lavene's variance). Tukey test HSD was applied for division into uniform groups. The ANOVA $(p<0.05)$ was done using the Statistica 13 software. 
Table 2. The constants of the HHV models (HHV in MJ/kg).

\begin{tabular}{|c|c|c|c|c|c|c|}
\hline \multirow{2}{*}{$\begin{array}{c}\text { Model } \\
\text { No. }\end{array}$} & \multirow{2}{*}{$\begin{array}{l}\text { Model } \\
\text { constants } \\
\text { No. }\end{array}$} & \multicolumn{4}{|c|}{ Model constants values } & \multirow[b]{2}{*}{ References } \\
\hline & & $x_{0}$ & $x_{1}$ & $x_{2}$ & $x_{3}$ & \\
\hline 1 & $c 1$ & 19.914 & -0.2324 & & & [10] \\
\hline 2 & $c 1$ & 14.119 & 0.196 & - & - & {$[7,14]$} \\
\hline 3 & $c l$ & 22.3418 & -0.1136 & -0.3983 & - & {$[27]$} \\
\hline 4 & $c l$ & 18.297 & -0.4128 & 35.8 & - & [27] \\
\hline \multirow{3}{*}{5} & $c 1$ & - & 0.312 & 0.1534 & - & [14] \\
\hline & $c 2$ & - & 0.3543 & 0.1708 & - & [16] \\
\hline & $c 3$ & - & 0.1905 & 0.2521 & - & [11] \\
\hline 6 & $c l$ & 44.366 & 0.286 & -2394.7 & - & [27] \\
\hline 7 & $c l$ & 28.296 & -0.2887 & -656.2 & - & [27] \\
\hline \multirow{2}{*}{8} & $c 1$ & -3.0368 & 0.2218 & 0.2601 & - & {$[10]$} \\
\hline & $c 2$ & -17.507 & 0.3985 & 0.2875 & - & [27] \\
\hline \multirow{2}{*}{9} & $c 1$ & 0.03543 & -0.1835 & -0.3543 & - & [16] \\
\hline & $c 2$ & 10.982 & 0.1136 & -0.2848 & - & [27] \\
\hline 10 & $c l$ & -10.8141 & 0.3133 & - & - & [13] \\
\hline \multirow{2}{*}{11} & $c 1$ & 23.068 & -0.157 & -0.047 & -0.583 & \multirow{2}{*}{ [6] } \\
\hline & $c 2$ & 22.543 & -0.234 & -0.0343 & -0.344 & \\
\hline 12 & $c 1$ & 167.2 & -1.449 & -1.562 & -1.846 & [27] \\
\hline 13 & $c 1$ & -18.37 & -0.8469 & -1.1251 & 4420 & [27] \\
\hline 14 & $c 1$ & - & 0.3536 & 0.1559 & -0.0078 & [17] \\
\hline \multirow{4}{*}{15} & $c 1$ & 1.3178 & 0.3699 & - & - & \multirow{2}{*}{ [1] } \\
\hline & $c 2$ & -0.459 & 0.4084 & - & - & \\
\hline & $c 3$ & -1.6701 & 0.4373 & - & - & [9] \\
\hline & $c 4$ & 3.4597 & 0.3259 & & & [10] \\
\hline \multirow{2}{*}{16} & $c 1$ & -1.6938 & 0.3856 & - & - & \multirow{2}{*}{ [1] } \\
\hline & $c 2$ & -3.4085 & 0.4182 & - & - & \\
\hline 17 & $c l$ & - & 0.2949 & 0.8250 & - & [11] \\
\hline 18 & $c l$ & - & 0.2828 & 0.4061 & - & [4] \\
\hline 19 & $c 1$ & -2.0611 & 0.3003 & 0.4508 & - & {$[4]$} \\
\hline 20 & $c 1$ & -3.5208 & 0.2424 & 0.4037 & 0.6131 & [4] \\
\hline
\end{tabular}

\section{Results}

Results of measurement of ash, carbon, fixed carbon, hydrogen, moisture, volatile materials content, nitrogen and HHV are presented in Table 3.

Table 3. Results of ultimate, proximate analysis and HHV measurement of the oat.

\begin{tabular}{|l|c|c|c|c|c|c|c|c|}
\hline \multirow{2}{*}{ Material } & \multicolumn{5}{|c|}{ Content (wt\%) } & \multirow{2}{*}{$\begin{array}{c}\text { HHV, } \\
\text { MJJ/kg }\end{array}$} \\
\cline { 2 - 8 } & $\mathbf{A}$ & $\mathbf{C}$ & $\mathbf{F C}$ & $\mathbf{H}$ & $\mathbf{M C}^{*}$ & $\mathbf{V M}$ & $\mathbf{N}$ & $\mathbf{1}$ \\
\hline Oat grain & $2.5 \pm 0.1^{\mathrm{a}}$ & $43.7 \pm 0.2^{\mathrm{a}}$ & $14.5 \pm 0.7^{\mathrm{a}}$ & $5.6 \pm 0.1^{\mathrm{a}}$ & $10.7 \pm 0.5^{\mathrm{a}}$ & $83 \pm 0.5^{\mathrm{a}}$ & $1.7 \pm 0.1^{\mathrm{a}}$ & $19.4 \pm 0.1^{\mathrm{a}}$ \\
\hline Oat straw & $9.2 \pm 2.3^{\mathrm{b}}$ & $40.2 \pm 1.2^{\mathrm{b}}$ & $18.2 \pm 1.2^{\mathrm{b}}$ & $4.8 \pm 0.2^{\mathrm{b}}$ & $12.5 \pm 0.5^{\mathrm{a}}$ & $72.6 \pm 1.5^{\mathrm{b}}$ & $0.6 \pm 0.2^{\mathrm{b}}$ & $17.6 \pm 0.6^{\mathrm{b}}$ \\
\hline
\end{tabular}

${ }^{a}, b$ the same letters in the columns indicated homogenous groups $(\mathrm{p}<0.05)$

${ }^{*} \mathrm{MC}$ - moisture content, $\mathrm{wt} \%$ 
The oat grain contains $43.7 \%$ of carbon, $5.6 \%$ of hydrogen, and $1.7 \%$ of nitrogen. Comparing with oat straw, oat grain contains more $\mathrm{C}, \mathrm{H}, \mathrm{N}$ by $3.5 \%, 0.8 \%$, and $1.1 \%$, respectively. Differences are statistically significant.

The oat grain contains $2.5 \%$ of ash, $14.5 \%$ of fixed carbon content, and $83.0 \%$ of volatile materials content (comparing with oat straw: less by $6.7 \%$ for ash and by $3.7 \%$ for fixed carbon content and more by $10,4 \%$ for volatile materials content). Differences are statistically significant.

Table 4 shows the contents of ash, C, H, N and the values of HHV in the grain and straw of oat as presented in the literature.

Table 4. Contents of A, C, H, N and the values of HHV in the grain and straw of oat.

\begin{tabular}{|c|c|c|c|c|c|}
\hline \multirow{2}{*}{ Material } & \multicolumn{4}{|c|}{ Content (wt\%) } & \multirow{2}{*}{ HHV, MJ/kg } \\
\cline { 2 - 5 } & $\mathbf{A}$ & $\mathbf{C}$ & $\mathbf{H}$ & $\mathbf{N}$ & \\
\hline \multirow{3}{*}{ Oat grain } & $2.3^{[28]}, 3.1[29]$, & $45.2^{[34]}, 47.6^{[29]}$, & $7.2^{[34]}, 6.6^{[29]}$ & $2.4^{[34]}, 2.2^{[29]}$, & $18.4^{[28]}, 17.6^{[30]}, 19.3^{[31]}$, \\
& $2.2^{[30]}, 2.9[31]$ & $5.4^{[33]}, 17.3^{[35]}, 18.0^{[25]}$, \\
& $5.8^{[32]}, 2.4^{[33]}$ & $43.6^{[30]}$ & $5.4^{[30]}$ & $2.1^{[30]}, 1.8^{[31]}$ & $16.6^{[325]}$ \\
\hline \multirow{2}{*}{ Oat straw } & $4.99^{[33]}$, & $46.2^{[34]}, 40.6^{[36]}$ & $6.4^{[34]}$, & $1.4^{[34]}$, & $19.15^{\left[366^{*}\right.}, 19.66^{[36]^{*}}$, \\
& $3.3^{[36]}$ & $5.2^{[36]}$ & $0.6^{[36]}$ & $19.06^{[36]^{*}}$ \\
\hline
\end{tabular}

*calculated form LHV in accordance with [37]

The obtained contents of carbon, hydrogen and nitrogen in the grain and straw of oat are lower than presented in the literature (only Głowacka et al. [30] reported lower contents of $\mathrm{H}$ ). The ash content in oat grain was similar to reported in the literature, however Heinzel et al. [32] and Bäfver et al. [29] noted higher values (5.8 and 3.1\%, respectively). The ash content in oat straw was higher than presented in the literature.

The obtained HHV of grain is higher than HHV of straw oat (Table 3) and differences are statistically significant. The obtained values of oat grain HHV are higher and values of oat straw HHV are lower than presented in the literature (Table 4).

Results of HHV modelling are presented in Table 5.

The possibility of using twenty models from the literature to describe HHV of oat grain, oat straw and both were examined. As can be seen from the analysis results, models (1) and $(8)_{c l}$ (model (8) with constants $\left.c 1\right)$ can be considered as the best for describing the HHV of oat. The RMSE values were $0.13,0.19$ and 0.16 for model (1) and 0.28, 0.21 and 0.25 for model $(8)_{c l}$ for grain, straw and both grain and straw, respectively.

The following models can be accepted for determining the HHV of oat grains: model (1) $(\mathrm{RMSE}=0.13)$, model $(5)_{c 2}(\mathrm{RMSE}=0.20)$, model $(11)_{c 1}(\mathrm{RMSE}=0.21)$, models $(8)_{c l}$ and (6) $(\mathrm{RMSE}=0.28)$, models $(12)$ and (7) $(\mathrm{RMSE}=0.29)$, models $(9)_{c 2}$ and (3) $(\mathrm{RMSE}=0.31)$. The models: (14), (1), (8) (10) and (2) can be used for estimation of the HHV of oat straw. The RMSE values were following: $0.12,0.19,0.21,0.21$ and 0.36 , respectively. Whereas the models: (1), (8) $c l$ and (10) are also recommended for modelling both oat grain and straw HHV. The RMSE values were equal $0.16,0.25$ and 0.29 , respectively.

Models (2) and (14) recommended for straw HHV calculation, give bad results (RMSE: 2.45 and 1.37) for grain HHV. Similarly, model (5) ${ }_{c 2}$ is recommended for HHV of grain calculation, while this model for HHV of straw and the model with other constants (c1 and $c 3$ ) give bad results for both oat grain and straw (1.24 $\leq \mathrm{RMSE} \leq 4.22)$. For the other recommended for grain models: (9), (12), (3), (6), (7), the accuracy for HHV of oat straw calculation is worse (RMSE $>1.05)$. 
Table 5. Results of oat HHV modelling.

\begin{tabular}{|c|c|c|c|c|c|c|c|c|c|}
\hline \multirow{2}{*}{$\begin{array}{l}\text { Model } \\
\text { No. }\end{array}$} & \multirow{2}{*}{$\begin{array}{l}\text { Model } \\
\text { constants } \\
\text { No. } \\
\end{array}$} & \multicolumn{3}{|c|}{ RMSE } & \multirow{2}{*}{$\begin{array}{l}\text { Model } \\
\text { No. }\end{array}$} & \multirow{2}{*}{\begin{tabular}{|l|l} 
Model \\
constants \\
No. \\
\end{tabular}} & \multicolumn{3}{|c|}{ RMSE } \\
\hline & & $\begin{array}{l}\text { oat } \\
\text { grain }\end{array}$ & $\begin{array}{l}\begin{array}{l}\text { oat } \\
\text { straw }\end{array} \\
\end{array}$ & $\begin{array}{l}\text { oat (grain } \\
\text { and straw) }\end{array}$ & & & \begin{tabular}{|l} 
oat \\
grain
\end{tabular} & $\begin{array}{l}\text { oat } \\
\text { straw }\end{array}$ & \begin{tabular}{|l|} 
oat (grain \\
and straw)
\end{tabular} \\
\hline 1 & $c 1$ & 0.13 & 0.19 & 0.16 & \multirow{2}{*}{11} & $c 1$ & 0.21 & 1.52 & 2.01 \\
\hline 2 & $c 1$ & 2.45 & 0.36 & 1.75 & & $c 2$ & 0.35 & 2.55 & 1.10 \\
\hline 3 & $c 1$ & 0.31 & 1.05 & 0.77 & 12 & $c 1$ & 0.29 & 1.07 & 0.78 \\
\hline 4 & $c 1$ & 0.35 & 1.19 & 0.88 & 13 & $c 1$ & 0.41 & 0.85 & 0.67 \\
\hline \multirow{3}{*}{5} & $c 1$ & 2.15 & 0.80 & 1.63 & 14 & $c 1$ & 1.37 & 0.12 & 0.97 \\
\hline & $c 2$ & 0.20 & 1.24 & 0.89 & \multirow{4}{*}{15} & $c 1$ & 1.92 & 1.44 & 1.70 \\
\hline & $c 3$ & 4.28 & 4.16 & 4.22 & & $c 2$ & 2.02 & 1.67 & 1.85 \\
\hline 6 & $c 1$ & 0.28 & 1.11 & 0.81 & & $c 3$ & 1.96 & 1.72 & 1.85 \\
\hline 7 & $c 1$ & 0.29 & 1.07 & 0.78 & & $c 4$ & 1.71 & 1.08 & 1.43 \\
\hline \multirow{2}{*}{8} & $c 1$ & 0.28 & 0.21 & 0.25 & \multirow{2}{*}{16} & $c 1$ & 2.07 & 1.96 & 2.02 \\
\hline & $c 2$ & 0.35 & 1.00 & 0.75 & & $c 2$ & 2.18 & 2.21 & 2.20 \\
\hline \multirow{2}{*}{9} & $c 1$ & 3.34 & 1.50 & 2.59 & 17 & $c 1$ & 1.87 & 2.83 & 1.83 \\
\hline & $c 2$ & 0.31 & 1.05 & 0.77 & 18 & $c 1$ & 1.19 & 1.14 & 1.16 \\
\hline \multirow{2}{*}{10} & \multirow{2}{*}{$c 1$} & \multirow{2}{*}{0.35} & \multirow{2}{*}{0.21} & \multirow{2}{*}{0.29} & 19 & $c 1$ & 1.26 & 1.39 & 1.33 \\
\hline & & & & & 20 & $c 1$ & 1.42 & 1.83 & 1.64 \\
\hline
\end{tabular}

Recommended models are based on the proximate analysis. They are the relationship between the HHV and content of ash, fixed carbon, moisture and volatile materials. Taken into account models based on ultimate analysis give worse results for oat HHV calculation than proximate models.

\section{Conclusions}

1. The following models are recommended for the prediction of HHV of oat (grain, straw and both grain and straw): $\mathrm{HHV}=19.914-0.2324 \mathrm{~A}$ and $\mathrm{HHV}=$ $3.0368+0.2218 \mathrm{VM}+0.2601 \mathrm{FC}(0.13 \leq \mathrm{RMSE} \leq 0.28)$.

2. The following model: $\mathrm{HHV}=19.914-0.2324 \mathrm{~A}$ is recommended for the calculation of HHV of oat grain $(\mathrm{RMSE}=0.13)$.

3. The following model: $\mathrm{HHV}=0.3536 \mathrm{FC}+0.1559 \mathrm{VM}-0.0078 \mathrm{~A}$ is recommended for the estimation of HHV of oat straw (RMSE $=0.12$ ).

4. The models based on ultimate analysis give worse results for oat HHV calculation than models based on proximate analysis.

\section{References}

1. A. Demirbaş and A. H. Demirbaş, Energy Explor. Exploit. 22,135(2004)

2. H. Uzun, Z. Yıldız, J. L. Goldfarb, S. Ceylan, Bioresour. Technol. 234,122(2017) 
3. S. B. Ghugare, S. Tiwary, S. S. Tambe, Int. J. Syst. Assur. Eng. Manag. 8,2083 (2017)

4. A. Ozyuguran, A. Akturk, S. Yaman, Fuel 214,640(2018)

5. S. A. Channiwala, P. P. Parikh, Fuel 81,1051(2002)

6. G. D. Gillespie, C. D. Everard, C. C. Fagan, K. P. McDonnell, Fuel 111,771(2013)

7. A. Demirbas, Energy Explor. Exploit. 20,105(2002)

8. V. K. Moka, Estimation of Calorific Value of Biomass from Its Elementary Components by Regression Analysis (NIT, 2012)

9. D. A. Tillman, Wood as an Energy Resource (Elsevier, 1978)

10. C. Sheng and J. L. T. Azevedo, Biomass Bioenergy 28,499(2005)

11. C.-Y. Yin, Fuel 90,1128(2011)

12. R. Galhano dos Santos, J. M. Bordado, Fuel 212,431(2018)

13. L. Jiménez, F. González, Fuel 70,947(1991)

14. A. Demirbaş, Fuel 76,431(1997)

15. R. A. Corbitt, Standard Handbook of Environmental Engineering (McGraw-Hill, 1999)

16. T. Cordero, F. Marquez, J. Rodriguez-Mirasol, J. J. Rodriguez, Fuel 80,1567(2001)

17. J. Parikh, S. Channiwala, G. Ghosal, Fuel 84,487(2005)

18. A. Demirbaş, Energy Convers. Manag. 41,1609(2000)

19. A. DemirbaŞ, Pet. Sci. Technol. 16,785(1998)

20. A. Demirbaş, Energy Convers. Manag. 42,183(2001)

21. D. Kavšek, A. Bednárová, M. Biro, R. Kranvogl, D. Vončina, E. Beinrohr, Open Chem. 11,(2013)

22. A. Friedl, E. Padouvas, H. Rotter, K. Varmuza, Anal. Chim. Acta 544,191(2005)

23. E. Malinowska, B. Wiśniewska-Kadżajan, K. Jankowski, J. Sosnowski, H. Wyrębek, Zesz. Nauk. Uniw. Przyr.-Humanist. w Siedlcach, 102,49(2014)

24. L. Spiss, Biul. Inst. Hod. Aklim. Roślin 229,7(2003)

25. A. Żabiński, U. Sadowska, G. Wcisło, Inż. Rol. 2,353(2012)

26. P. Basu, in Biomass Gasif. Des. Handb. (Elsevier, 2010)

27. A. Özyuğuran, S. Yaman, Energy Procedia 107,130(2017)

28. R. Tobiasz-Salach, E. Pyrek-Bajcar, D. Bobrecka-Jamro, ECONTECHMOD: Int. Q. J. Econ. Technol. Model. Proc. 5,35(2016)

29. L. S. Bäfver, M. Rönnbäck, B. Leckner, F. Claesson, C. Tullin, Fuel Process. Technol. 90,353(2009)

30. A. Głowacka, M. Zych, J. Żołnierczuk, Inż. Ekol. 117(2016)

31. A. Keppel, J. Finnan, B. Rice, P. Owende, K. MacDonnell, Biosyst. Eng. 115,136(2013)

32. T. Heinzel, V. Siegle, H. Spliethoff, K. R. G. Hein, Fuel Process. Technol. 54,109(1998)

33. J. Mółka, B. Łapczyńska-Kordon, Inż. Rol. 6,141(2011)

34. S. Poskrobko, D. Król, J. Therm. Anal. Calorim. 109,629(2012)

35. E. Kaszkowiak, J. Kaszkowiak, Inż. Apar. Chem. 50,33(2011)

36. Y. Zhang, X. Gao, B. Li, H. Zhang, Energy Sources Part Recovery Util. Environ. Eff. 38,1574(2016)

37. S. Van Loo, J. Koppejan, The Handbook of Biomass Combustion and Co-Firing (Earthscan, 2008) 